Agro-Science Journal of Tropical Agriculture, Food, Environment and Extension Volume 20 Number 4 (Special Issue, October 2021) pp. $36-45$

ISSN 1119-7455

\title{
STEMMING RURAL-URBAN MIGRATION THROUGH AGRICULTURAL DEVELOPMENT: CAN NIGERIA APPLY THE LESSONS FROM THE COVID-19 PANDEMIC?
}

\author{
*Agwu A.E., Anugwa I.Q. and Ifeonu C.F. \\ Department of Agricultural Extension, University of Nigeria, Nsukka 410001, Nigeria \\ *Corresponding author's email: ekwe.agwu@unn.edu.ng
}

\begin{abstract}
Nigeria has one of the highest population growth rates in the world resulting to rapid urbanization and an enormous increase in the population leaving rural areas and now living in urban centres. In spite of the increased emphasis on rural development, rural-urban migration has persisted mainly due to the farmerherder conflict situation, poverty, lack of job opportunities, insecurity and gross inadequacy of social infrastructures in the rural areas. This mass migration and other factors have put Nigeria in an emergency food and nutrition insecure situation. Before the COVID-19 pandemic, there was already an existing gap in the Nigerian food system, which led to the importation of food items to augment local production in order to meet local demand. However, the emergence of the COVID-19 pandemic undermined efforts to achieve SDG 2 as the country witnessed not only a major disruption to food supply chains in the wake of lockdowns and movement restrictions triggered by the global health crisis, but also a major economic slowdown. The commerce, service, and agricultural sectors were the hardest hit by the spread of the virus and the effects are different along the rural-urban continuum. The vacuum created by the migration of people from the rural to urban areas led to reduction of farm yields, while the urban areas were particularly affected in terms of food supply from rural areas as a result of movement restrictions made during the height of the pandemic. More urbanised areas may be harder hit than remote rural areas if connectivity remains broken down, as most food crops are produced in the rural and semi-rural areas. This paper recommends strategies and policies aimed at reducing poverty, food insecurity and inequality across the urban-rural continuum through agricultural development. This will assist in addressing the adverse drivers of migration with particular focus on improving the social and economic conditions of rural areas.
\end{abstract}

Key words: agricultural development, COVID-19, food security, rural-urban migration

\section{INTRODUCTION}

Agriculture is the bedrock of the Nigerian economy, providing the main source of livelihood for the majority of the rural populace (Food and Agriculture Organization, 2019). According to World Bank (2019) report, rural population in Nigeria has decreased over the years from an estimated $84.59 \%$ in 1960 to $48.84 \%$ in 2019 , and these rural dwellers rely largely on farming for food and earnings. Evidence has shown that majority of the population in most rural areas are small-scale farmers providing food for human consumption and raw materials for export and manufacturing industries (Adeniyi et al., 2020). Agriculture also serves as a major source of employment to most rural people. However, agricultural development in rural areas in Nigeria is constrained by a couple of factors such as the use of crude tools, limited financial and technical support, poor transportation network, inadequate land due to land tenure system, problems of pests and diseases, lack of storage and processing facilities, inadequate agricultural education and extension services, negative attitude of people towards farming due to the low reward associated with it, and rural-urban migration, among others (Akanbi and Akinyoade, 2014; Udemezue, 2019).

Rural-urban migration is one of the most distressing problems facing the Nigerian agriculture. It represents a phenomenon of unprecedented movement of people from the rural countryside to the urban cities in search of a better life (Ajaero and Onokala, 2013). It is also a situation where the desire for better employment, business opportunities and education cause both young and old to migrate from the rural areas to urban areas. Rural-urban migration is the most important aspect of labour migration because it affects the structures and composition of the population. It has been a major driver of Nigeria's rapid urbanization, resulting mainly from higher potential economic opportunities and income in urban areas as well as the demographic pressure on natural resources in rural areas (Oginni and Tahirou, 2019). Nigeria has witnessed high rates of urbanization in the last two decades. Between 1960 and 2018, the urban population in

Please cite as: Agwu A.E., Anugwa I.Q. and Ifeonu C.F. (2021). Stemming rural-urban migration through agricultural development: can Nigeria apply the lessons from the COVID-19 pandemic? Agro-Science, 20 (4, Special Issue), 36-45. DOI: https://dx.doi.org/10.4314/as.v20i4.5 
Nigeria has grown rapidly from $15.4 \%$ to $48.9 \%$ (Oni-Jimoh et al., 2018). According to Farrell (2018), the country is projected to have an additional urban population of 226 million inhabitants by 2050 , and this means three times more than the size of its current urban population.

Inadequate infrastructural facilities in urban areas, urban congestion, lack of opportunities for remunerative work, neglect of agricultural sector have all been linked to rural-migration (Mbah et al., 2016; Alarima, 2018). The mass migration of people especially the youths from rural to urban areas has negative implications for agricultural productivity in rural Nigeria (FAO et al., 2018). As young people migrate to urban areas to seek better standard of living, many aged individuals are left to carry out the majority of farm work. These added responsibilities to the aged ones undoubtedly impair their productive capacity as they already lack the required energy to do most farming activities. Consequently, these have resulted to labour shortages, disrupted intra-household labour substitution patterns, and increased the cost of farm labour because only few youths are left behind in rural areas. It also led to a decline in agricultural production and yield, as well as higher cost of food, thereby putting food out of reach for many and undermining their right to food. These could likely stall efforts to meet the Sustainable Development Goal (SDG) 2: "Zero hunger" (High Level Panel of Experts on Food Security and Nutrition, 2020) especially during the COVID 19 pandemic.

The outbreak of COVID-19 pandemic on the $11^{\text {th }}$ of March 2020, which coincided with the start of the rains and the peak of cropping season for labour intensive staple food and vegetable production, exacerbated the food insecurity situation and incidence of high level of poverty in Nigeria (Amare et al., 2020; Ayanlade and Radeny, 2020). The reason is because, many Nigeria's crops are grown under rain-fed conditions and planting time is critical, hence delays in planting during the rainy season as a result of movement restrictions had a substantial impact on crop growth and led to a food shortfall. Moreover, the Nigerian government's movement restrictions in response to the pandemic resulted in a loss of economic activity, forcing most farming households to abandon their existing farms and those under cultivation, as well as affecting the supply or access to essential farm inputs such as seeds, fertilizers, pesticides, fish fingerlings and feed (Ayanlade and Radeny, 2020; Ofuoku et al., 2021). Also, agricultural extension and advisory services have been severely disrupted as a result of the lockdown measures, limiting farmers' access to information during the critical growing period.

The vacuum created by the migration of people, particularly the youths from the rural to urban areas, resulted in farm labour shortages and had huge impact on production and processing of food during the pandemic. At the rural areas, the impact was felt in terms of less household members able to support food production and harvest thereby limiting farm yields. It also resulted to less demand for produce from the urban areas due to movement restrictions leading to post-harvest losses. More so, due to the shutdown of economic activities, the pandemic had a negative impact on purchasing power of urban dwellers; many self-employed workers saw their incomes plummet; some employees in the private sector were laid off; and others' salaries were either slashed or stopped entirely (International Labour Organisation, 2020; Organisation for Economic Co-operation and Development, 2020).

Rapid urbanization and rural transition had already raised public concern prior to COVID-19 pandemic in Nigeria (Aliyu and Amadu, 2017; Farrell, 2018; Kuddus et al., 2020). It necessitated the need to balance strategies and policies to eliminate poverty and food insecurity and increase agricultural development in rural areas. Furthermore, the current pandemic crisis and its aftermath, which worsened the food insecurity situation in Nigeria, have brought to bare the need for more integrated approaches to stem rural-urban migration. Based on the foregoing, this article raises the following pertinent questions: What are the causes of rural-urban migration? What are the effects of rural-urban migration on agricultural production? How does the emergence of COVID19 impact negatively on agricultural production due to rural-urban migration? What are the strategies for reducing rural-urban migration through agricultural development in light of the new challenges introduced by COVID 19 ?

\section{Causes of Rural-Urban Migration}

One major livelihood strategy developed by the rural poor is to move out of their homes in search of greener pastures. Fundamental to the understanding of rural-urban migration flow are the traditional "push-pull" factors developed by Anaglo et al. (2014). The migration or immigration of particular populations from one land to another is influenced by a mixture of push-pull variables. The push factors, according to Alarima (2018) and Rosenberg (2021), are the events that cause people to leave their homes and relocate. Examples such as famine, drought, low agricultural productivity, declining incomes in agriculture, the inadequacy of incomes, lack of gainful employment coupled with poverty in rural areas have all forced people out of their villages in pursuit of better sources of livelihood in the cities (FAO et al., 2018).

The factors that lure rural migrants to cities are known as pull factors (Alarima, 2018; Hoffmann et al., 2019; Rosenberg, 2021). Urban employment prospects, housing conditions, better education and greater income options are examples of these factors. Apart from these considerations, there is no 
doubt that urban places provide the opportunity to live a better lifestyle due to the availability of services such as electricity, pipe-borne water, and public services (FAO et al., 2018).

Voluntary or involuntary forces could trigger rural-urban migration. Migration that occurs when a migrant has no option but to move (Ajaero and Onokala, 2013; World Economic Forum, 2017; Johnson and Ifeoma, 2018) is known as involuntary or forced migration. Examples include ethnoreligious crises, conflicts and wars, political strife, family and land disputes, conflicts with neighbours, among others. On the other hand, voluntary migration refers to mobility that is made on one's own volition (Ajaero and Onokala, 2013; Erdal and Oeppen, 2018). Urban work possibilities, better housing circumstances, rural land tenure and inheritance patterns, better education options, better health services, extreme poverty, and other factors all contribute to voluntary rural-urban migration (Alarima, 2018; Johnson and Ifeoma, 2018; FAO, 2019). Rural residents frequently witness and hear success stories about people who have left the village, relocated to cities, and are allegedly 'doing well.' This encourages out-migration, particularly among young people. One interesting characteristic of these migrants is that some of them lack the requisite skills or education to find a job in the formal sector in urban areas and they sometimes end up not achieving what they set out to do.

Summarily, the causes of rural-urban migration are highlighted and discussed below:

i. Economic Factors: These factors pertain to urban areas labour market, job status, and overall economic health. The favourable economic conditions in urban areas, the potential of greater earnings, better employment chances, and wealth creation potential, as well as a desire to flee their home region's domestic social and political circumstances, is what attract rural migrants to urban areas (World Economic Forum, 2017). The economic conditions in rural areas are unfavourable compelling the poor and unemployed people to move in order to survive. Unemployment or a lack of job possibilities, rural poverty, high food prices and unsustainable livelihoods are all economic push factors (FAO et al., 2018).

ii. Socio-Political Factors: The socio-political factors that contribute to migration include family conflicts and disunity; the drive for independence; ethnic, religious, racial, and cultural characteristics; warfare, or the prospect of conflict, among others (Parrish et al., 2020). Political instability, poor policy execution, misuse of funds, insufficient data, resource misallocation, safety and security concerns, conflicts or the fear of conflict, slavery or bonded labour, inadequate or limited urban services and infrastructure such as (a) poor housing with small, overcrowded houses built using inferior materials and an unstable electricity supply (Johnson and Ifeoma., 2018), (b) limited access to water resources (Newborne, 2016), (c) lack of sanitation/latrines and no solid waste disposal facilities resulting in a contaminated and deteriorated local environment (d) insufficient health-care facilities, which, when combined with poor living conditions, leads to increased illness and death rates (Aliyu and Amadu, 2017) are some of the examples of socio-political push factors.

iii. Ecological Factors: According to Parrish et al. (2020), environmental concerns such as climate change and the scarcity of natural resources drive people to move in pursuit of better ecological conditions. Climate change (such as extreme weather occurrences, rainfall variability, disaster events-such as flooding, desertification), changes in land cover, overexploited natural resources, crop failure, and food scarcity are all ecological push factors.

\section{Effects of Rural-Urban Migration on Agricultural Production}

Rural-urban migration is a double-edge problem affecting both rural and urban communities. Migration from rural to urban areas reduces the number of people living in rural areas, which has a negative impact on agricultural output and slows the pace of growth in rural areas (Johnson and Ifeoma, 2018). As teenagers and young adults leave villages and rural communities, the elderly, women, and children are left to work on fields, resulting in a decrease in agricultural production/output which has an impact on the nation's gross domestic product, reduced funds for development, income and standard of living of rural residents, underdevelopment, and food insecurity (Anaglo et al., 2014; FAO et al., 2018). Also, the earning differential between the urban and rural sectors, causes the highly educated and agile people to migrate from rural to urban areas, leaving behind the weaker and uneducated individuals who are unable to sustain agricultural production (Johnson and Ifeoma, 2018; Oguche et al., 2020).

Food supplies and distribution are also strained as a result of population shifts (Askew, 2017; Frona et al., 2019). People who migrate to cities are more likely to buy food rather than grow their own, making them vulnerable to price fluctuations. It becomes more difficult to boost food production in a sustainable manner as the population expands and the demand for water and land grows. Increased urban demand, along with the loss of agricultural land, puts increased pressure on rural people to feed an everincreasing metropolitan population (Barrett, 2020). In addition, pollution from urban areas has the potential to impair food production. For example, urban household garbage and liquid effluents from city-based industry frequently harm fisheries (Aubry and Manouchehri, 2019; Nicholls et al., 2020). 
Oguche et al. (2020) further note that the ongoing decline in rural population resulted in government's neglect of rural areas, as they tend to focus on developing the more obviously populated urban centres. This feeds into the vicious cycle of rural neglect and underdevelopment, as seen by a lack of rural industry and inadequate physical, social, and institutional infrastructure. Most often, rural agricultural development policies or programs are discontinued whenever there is a change in government leadership. New government abandons agricultural projects and programs of its predecessor even when such programs are appropriate (Oguche et al., 2020). In this regard, there is usually the absence of sustained, comprehensive and conclusive implementation of rural agricultural development policies (Ajadi, 2010).

Rural-urban migration has led to changes in rural land use, in terms of farmland abandonment, which has in turn affected rural biodiversity and weakened agricultural cultivation due to labour outmigration (Zhang et al., 2020). The impacts of rural-urban migration on agricultural production have further resulted to changes in farmer household's financial capital due to technical efficiency and agricultural market changes (Wang and $\mathrm{Yu}, 2019)$. However, rural-urban migration also has positive effects on agricultural production. Rural-urban migrants send remittances to their relatives in rural areas and these remittances are often used to purchase farm inputs and rent substitutes for labour thereby stimulating crop and livestock production (Ajaero and Onokala, 2013).

\section{Rural-Urban Migration and \\ COVID-19 Pandemic in Nigeria}

Brief history of COVID-19 pandemic in Nigeria

With the largest population in Sub-Saharan Africa and long-established travel and commercial linkages within Africa and the rest of the world, the COVID-19 pandemic seemed destined to reach Nigeria. Nigeria recorded the subcontinent's first confirmed case on $27^{\text {th }}$ of February, 2020, when a traveller arriving in Lagos from Europe contracted the virus, which then spread throughout Lagos, Ogun State, and the Federal Capital Territory (FCT) area of Abuja (Andam et al., 2020a; Nigeria Centre for Disease Control, NCDC, 2020).

In response, the government increased funding for the Nigeria Centre for Disease Control (NCDC) to boost laboratory testing and isolation capacity by US\$ 27 million in 2020 (International Monetary Fund, 2020). A Presidential Task Force was constituted in early March 2020 (Ameh, 2020; Andam et al., 2020a) to manage the government's reaction. This Task Force worked closely with the NCDC, who was in charge of public health campaigns as well as the general management of patient testing, isolation, and treatment. The government also lunched public awareness programmes highlighting the importance of hand washing, maintaining physical distance from others, and avoiding large crowds (NCDC, 2020). The NCDC which was responsible to provide daily update of the level of COVID-19 in Nigeria had as at $12^{\text {th }}$ June, 2021 reported a cumulative number of 167,051 confirmed COVID-19 cases, 1,504 active cases, 163,430 discharged cases and 2,117 deaths across all the 36 states and Abuja (NCDC, 2021).

Nigeria's government was one of the first on the subcontinent to impose social distancing and directed lock down measures. School closures, limited trading hours in informal markets (food markets were only allowed to open twice/thrice a week depending on the state) and restrictions on large social gatherings such as religious and sporting events were all part of the lockdowns (Global Alliance for Improved Nutrition, 2020). They also shut down many businesses, borders that connected the lockdown states to the rest of the country and passenger air travel was also halted across the country (Federal Government of Nigeria, FGN, 2020). However, the Presidential Task Force exempted medical services, agricultural activities, food makers and merchants, telecommunications, and certain financial services (Presidential Task Force, 2020). According to Andam et al. (2020a), the Nigeria was one of the first developing countries to recognize the potential scale of COVID-19's economic consequences, and it was one of the first to announce fiscal and stimulus measures to mitigate the effects, including food distribution and a two-month advance payment of the government's conditional cash transfers to vulnerable citizens.

\section{Impact of COVID-19 on agriculture due to rural-urban migration}

The COVID-19 epidemic sparked a global economic downturn, resulting in widespread losses of livelihood and income (International Monetary Fund, 2020; World Bank, 2020a). Countrywide lockdown measures, including limited access to marketplaces led to many job losses. These policies have harmed the resource poor's income-earning prospects, lowered their purchasing power, caused them to use negative coping techniques, and exacerbated the poverty gap (FAO, 2020; Carducci et al., 2021). As a consequence of household's limited ability to afford balanced diet, it had quite a significant influence on food security and nutrition.

Although primary agricultural activities were exempted from the lockdown direct limitations on economic operations, the broader agri-food system was impacted indirectly due to its interconnections with the rest of the economy (Andam et al., 2020a). According to the International Food Policy Research Institute (IFPRI), the agricultural gross domestic product (GDP) decreased by $11 \%$ or US $\$ 1.6$ billion during the lockdown in Nigeria (Andam et al., 2020b). According to Andam et al. (2020a), losses in the agro- 
processing sector were substantial $(16.5 \%)$ due to restrictions imposed on non-essential industrial or services sectors that demand agro-processing products, resulting in their closure. Food and agricultural trade, as well as transportation services, fell by $10 \%$, and the near-total closure of hotels and restaurants within the lockdown zones exacerbated the food services sector's decline (Andam et al., 2020a).

Following lockdown efforts, the COVID-19 pandemic caused substantial disruptions in the five components of the food supply networks (agricultural production, postharvest handling, processing, distribution/retail/service, and consumption), affecting food availability, pricing, and quality (Aday and Aday, 2020; Barrett, 2020). It also retarded the delivery of food and agricultural inputs and created problems in providing continuous food supply to markets (ILO, 2020).

During the pandemic, labour shortages induced by migration had a major influence on food production and processing (OECD, 2020; Stephens et al., 2020). It caused major disruptions in various labour-intensive industries such as cattle husbandry, horticulture, planting, harvesting, and agricultural processing (Stephens et al., 2020). The impact was felt in rural areas in terms of fewer household members capable of supporting food production and harvest, lowering the season's yields, as well as decreased demand for produce from urban centres due to movement restrictions. The closure of restaurants and other food service facilities resulted in a significant drop in demand for perishable commodities such as dairy products, potatoes, and fresh fruits, as well as several high-value meat cuts (HLPE, 2020; Yaffe-Bellany and Corkery, 2020).

Nevertheless, COVID-19 has a detrimental effect mostly on labour-intensive food production among rural food system workforce who are largely children, women, and the elderly (HLPE, 2020). Older individuals are more likely to be very sick from COVID19, according to the Centre for Disease Control and Prevention (2021), as they are more likely to have medical conditions like cardiovascular disease, diabetes, or respiratory illness. This disrupted farms and agricultural enter-prises by affecting food production and availability, as well as the inability of foods to reach markets, putting upward pressure on the pricing of some scarce food items (Committee on World Food Security, 2020; Stewart et al., 2020). Women are also more likely to be exposed to COVID-19 in their roles as caregivers to the sick, which has implications for food production, processing, and trading (Moseley, 2020).

According to FAO, rural women's agricultural activities have been affected more than men's, as they suffer additional difficulties during COVID-19 because to their spouse's relocation (FAO, 2020). Women and their prominent roles in food systems, especially as primary actors in ensuring home food security and nutrition, as well as food producers, farm managers, food dealers, and wageworkers, were severely affected as their husbands who migrated before the COVID-19 lock down to seek greener pasture for the household could not return home. This led to the reduction in remittances from their husbands as a result of the COVID-19 outbreak and the accompanying lockdown and movement restrictions in urban areas (World Bank, 2020a). Therefore, because they are no longer able to care for the home, women may turn to coping tactics such as moving to less labour-intensive crops, renting out some of their land, or increasing their commercial activities (FAO, 2020).

Moreover, as schools close and more adults are restricted from moving, children may be compelled to assist their families in farm-related activities to make up for the shortage of adult workers, both on the family farm and as wage workers (FAO, 2020; ILO, 2020). Replacement of children on adult work on and off farms, according to FAO (2020), can expose them to hazardous duties and difficult labour. This is due to a lack of work experience, as well as understanding of hazards and risks, as well as risk mitigation and control strategies. Additionally, considering children's bodies and minds are still developing, frequent awkward or heavy lifting and repetitive stresses, for example, might permanently harm growing spines or limbs, and particularly if poorly built equipment is employed. Pesticide exposure might also have long-term health consequences that do not manifest themselves until the child is an adult.

Food production requires the use of inputs such as seeds and fertilisers and access to these inputs such has also been impeded by the lockdown, making them scarce and costly (FAO, 2020; Obayelu et al., 2021). The valuation and release of novel seed varieties, as well as the timely production of early generation seed and the planning of its supply, were all hindered by mobility restrictions and lockdowns. Despite government efforts to distribute seeds to farmers, seed producers' access to agro-inputs and mechanization services was impeded by mobility constraints (Global Alliance for Improved Nutrition, 2020).

According to Resnick (2020) and FAO (2020), the response to COVID-19 resulted in the closure or limited access to many informal markets in urban and peri-urban areas of Nigeria in order to avoid crowding, and this disrupted food supply systems. The shutdown affected both farmers and consumers because the markets served as venues for buying and selling of fresh food for low-income urban consumers and small retailers, who rely on these markets for $90 \%$ of their income (Resnick, 2020). It also restricted access to nutritious foodstuffs, as it occurred at a time when people are increasingly reliant on local foods such as fresh fruits, vegetables, meat, eggs, and milk (Stephen et al., 2020). These trade obstacles increased transaction costs, reducing smallholder farmers' profit margins and potentially reducing their on-farm investments (Obayelu et al., 2021). 
Logistical constraints are another potential supply shock triggered by COVID-19 (OECD, 2020). Despite the fact that the Nigerian government declared agricultural products to be essential commodity, in order to facilitate its movement, traders still faced logistical challenges, resulting in supply delays and post-harvest losses. This is because, even if food is accessible, actions undertaken to restrict the spread of the corona virus, such as the closure of borders or transportation links to urban centres, had impact on the distribution network. This is attributable to the fact that urban food supply relies on road transportation, as traders frequently travel to city centres on minibuses and many small transporters that connect producers and consumers were severely affected by these restrictions (Ayieko and Njeru, 2020). Following decreases in service operations, disruptions in container and truck transit used in supplying foodstuffs were also recorded (FAO, 2020; OECD, 2020).

\section{Strategies for Stemming Rural-Urban Migration through Agricultural Development in the Light of COVID-19 Pandemic}

COVID-19 has no borders, and this has aggravated agricultural problems in Nigeria, particularly in the area of rural-urban migration, necessitating an integrated strategy with methods and policies to address poverty, food insecurity and inequality in the rural region. Agricultural development is critical in reducing rural-urban migration in Nigeria, and it has the potential to change the way rural regions are handled, resulting in a change in Nigerian governance practices (Oguche et al., 2020).

According to Organisation for Economic Cooperation and Development (OCED), agricultural development is described as the process of creating the environment for agricultural potential to be achieved. World Bank (2020b) noted that agricultural development is one of the most powerful tools for eradicating extreme poverty, stimulating shared prosperity, and feeding a projected 9.7 billion people by 2050 as it is 2-4 times more effective in raising incomes among the poorest than growth in other sectors. It can be accomplished by providing subsidized inputs and outputs (such as improved seeds, fertilizer, and pesticides), providing credit, building infrastructure, knowledge accumulation, and making technology available, among other things, all of which will increase food production for rural dwellers and raise the income level of small-scale farmers (Omonijo et al., 2014; Mellor, 2017; World Bank, 2020b). Agricultural development has social and economic implications because small farmers can better feed their families, send their children to school, care for their health, and invest in their farms with higher income. As a result, their communities will be stronger and more stable economically, reducing rural-urban movement.
Agricultural development can help address the negative factors of migration while also focusing on the social and economic situations of rural communities. One approach to achieve this is to encourage the processing of food in rural regions, which will increase agricultural employment prospects and incomes in the rural sector (FAO et al., 2018). The fact that the majority of food processing firms are currently located in metropolitan areas can scarcely be explained other than by proximity to the market. However, if improving rural agricultural employment and incomes is prioritized, food processing firms, particularly those that handle primarily local raw materials, (e.g., cocoa and tomato processing industries), should be sited in rural areas. This offers the extra benefit of being close to the source of raw material resources. Besides, this will provide employment chances for at least $30 \%$ of rural residents in agricultural value chains and other agribusiness prospects; however, attention should be given to women and youth.

Second, procedures such as insurances, transfers, and input distribution (improved seeds, equipment and fertilizer) should be developed to safeguard farmers and small-scale agricultural producers from uncertainty and revenue losses (Pan et al., 2020). Dedicated and institutionalized financial facilities and other forms of support (particularly accessible to women and youth), such as fiscal incentives, emergency credit lines, and low-interest loan programmes, should be provided to farmer organizations/ cooperatives to stimulate agricultural production and increase their investment (FAO, 2020).

Third, more resilient food production systems based on agro-ecology (the study of exploiting ecological interactions within agricultural fields to boost crop yields while minimizing input costs and waste (HLPE, 2020) and other sustainable types of food production must be supported and invested in. Since it is a sustainable food production strategy that is accessible to all types of farmers, both affluent and poor, strengthening food system resilience is crucial for an effective response to the COVID-19 epidemic and other future crises (Altieri and Nicholls, 2020). Industrial food production techniques, which are the most effective approach to increase food production in rural regions, should also be promoted (Moseley, 2017; Gengenbach et al., 2018). However, more research and training are urgently needed to enable the shift to more agro-ecological agricultural methods that can strengthen food system resilience.

Fourth, there is a need to use and adapt existing information and communications technologies (ICT) based solutions to provide extension support to smallholder producers due to the risks posed by COVID-19, which limited extension agent visits, in-person training, and farmers meetings. The ICTs can help rural producers expand their networks, overcome information symmetries and better plan their activities by providing updated market informa- 
tion (e.g., prices of goods), as well as other services that are relevant to agriculture (e.g., weather forecasting) (FAO, 2019; Even and Nyathi, 2020). Also, virtual platforms can also be established for online mentoring and knowledge sharing. In this context, social media platforms like WhatsApp and Facebook should be used to relate with farmers and ensure real-time contact and speedier feedback on current actions. Beyond the current COVID issue, ICT will increase the efficiency, inclusivity, resilience, and timeliness of extended support.

Fifth, access to land (widely recognized as an important factor of production) and subsequent security of tenure are fundamental for young Nigerians in rural areas to engage in farming and will significantly shape their livelihood options (Yeboah et al., 2019). The disparities in access to land have significant consequences for youth's employment and migration options in many rural societies, as young people's migration decisions are also influenced by the potential of inheriting land (Kosec et al., 2017; Ghebru et al., 2018). This is because population pressure and the dwindling size of farm lands is reducing land availability to youths, and by extension, reducing their potential for long-term occupations in own farm production thereby leading to migration. As a result, in agricultural and rural development, property rights, tenure security, and land markets are crucial (Singirankabo and Ertsen, 2020). Tenure security encourages investment and increases land production, resulting in higher rural incomes and can facilitate the re-integration of returnees and prevent disputes over resources (Yeboah et al., 2019).

Sixth, in high-potential agricultural areas, rural infrastructure investment will have the greatest impact on both growth and poverty alleviation, hence reducing migration (Mellor, 2017). This can be achieved by regulating markets to boost agricultural commodity trade; investing in roads, electrification, and communications; and forming cooperatives to buy and sell agricultural products and streamline rural marketing (Dandekar, 2015). Improved infrastructure, such as roads and electrification, will motivate farmers by expanding the range of exotic items available to them, broadening their worldview, hence raising the motivation to adopt income-boosting technologies (Mellor, 2017). Rural electricity for agricultural production is linked to irrigation and cold storage facilities, among other things, while road construction has a significant impact on agricultural growth due to its linkage to urban regions, which improves trade and food supply.

Furthermore, improved infrastructure will bring more traders to the rural area, resulting in increased competition, reduced margins, and more favourable agricultural prices (Mellor, 2017; Gebre and Gebremedhin, 2019). Farm inputs such as fertilizer, seeds and herbicides will become more widely available, resulting in more agents/traders competing for business, lowering margins and improving pricing relationships. Improved infrastructure (roads, hospitals, and electrification) and accompanying advancements will encourage extension agents to visit more and conduct more demonstrations, as well as entice them to settle in the area because the amenities are adequate (Mellor, 2017). Due to weak rural infrastructure in rural places, the trip to work is typically long and tedious, so the temptation to skip a day is high. Other critical personnel, such as accountants, health workers, and cooperative managers, are also affected.

Again, rural youth can be engaged through multi-sector policies that promote complementary programs such as education, skill development, and seasonal job schemes, thereby reducing migration (FAO, 2019). People in rural areas can benefit from skill development programs and training in modern agricultural technologies, which can help them broaden their skill sets and encourage entrepreneurial activities that encourage rural development. Their adaptive capacity to shocks can be strengthened by the introduction and promotion of agro-ecology principles, climate smart agriculture (CSA) techniques, ecological restoration, green job creation, investments for equitable and sustainable access and use of natural resources, as well as good and inclusive governance of natural resources, particularly land and water. Nonetheless, a focus on free, mandatory elementary school education in rural areas will foster young people's interests and abilities while also improving the skills they need to compete for development advantages. According to Mellor (2017), education influences the rate of modernization and production growth in a variety of ways; it broadens horizons about consumption and thus the incentives to increase production, it expands the vocabulary for understanding technical issues, it simplifies the computation of economic returns, and it opens the mind to contributions from outsiders such as educated extension workers or researchers.

\section{Policy and Programme Recommendation to Stem Rural-Urban Migration in the Face of COVID-19 Pandemic}

The overall recommendation is that the government of Nigeria and development partners must consider and embrace the creation of the conditions necessary for rural and agricultural development. This can be achieved by:

i. Creating awareness on professionalization of agriculture activities. Many youths are leaving the rural areas because they see agriculture as tedious and not lucrative.

ii. Enhancing and diversifying employment opportunities in agri-food systems and green sectors, especially for women and youth; and helping the poor to better manage risks through social protection. 
iii. Creating infrastructure that are directly related to agricultural and private sector development, such as building roads to facilitate market access.

iv. Supporting farmer cooperatives and smalland mid-sized agricultural enterprises through grants and loans to expand and improve their operations to meet the needs of local communities during pandemics.

v. Establishing modern and resilient agri-food value chains project which will contribute to improving the efficiency of key value chains while investing in on- and off-farm technologies and practices to increase economic and climate resilience.

vi. Mobilizing emergency funding to benefit farm families to safeguard production for the next two cropping seasons, given that a reduction in remittances will affect the capacity of farmers to finance production costs.

vii. Creation and mobilization of women's selfhelp groups in order to meet shortages in food production, restore fresh food supplies, provide food and support to vulnerable and high-risk families.

viii. Fostering social cohesion to reduce tension and conflicts over natural resources for example access to land rental markets could provide an alternative to inherited land and facilitate youth self-employment in agriculture.

ix. Leveraging digital technologies through partnerships to transform the delivery of inputs, soil testing, crop insurance, credit, extension advice, market linkages, and online/digital sales of produce to enable farmers to overcome temporary COVIDrelated constraints and ensure better targeting and more effective service delivery, especially in remote areas in the long run.

\section{CONCLUSION}

Due to labour shortages, disrupted intra-household labour substitution patterns, and higher farm labour costs, the large migration of people, particularly youths, from rural to urban regions had negative repercussions for agricultural output in Nigeria, placing food out of reach for many. The outbreak of the COVID-19 pandemic in Nigeria has aggravated the country's food crisis on both the supply and demand sides. Due to the pandemic, movement restrictions impeded economic activity, potentially hurting food production, lessening the food supply and demand thereby increasing food insecurity. The challenges posed by the pandemic have once again emphasized the importance of the long-running debate in Nigeria regarding food security. As a result, reducing migration to urban areas through improving rural life and diversifying the agricultural sector has emerged as a top planning priority since the bulk of food is produced in rural regions. This can be accomplished by putting a ceiling on individual land holdings, reforming tenancy to strengthen the rights of those who cultivate the land, launching programs to provide better tools to traditional artisans, establishing and facilitating access to credit, and improving access to markets for both marketable products and inputs. There is need to strengthen agricultural value chains and food systems to boost diversification by providing job possibilities for rural populations, particularly youth, in both agricultural and non-agricultural industries. It is also critical to maximize the potential of information and communication technologies (ICTs) in the agricultural sector in order to improve access to extension services. Finally, the provision of amenities such as road, electricity, clean drinking water, healthcare and educational facilities, will make rural living more appealing. Therefore, the government must accelerate agricultural development in Nigeria, as the majority of the rural population expects. This is because people in rural areas would not need to relocate to urban centres if they have access to basic social amenities and other provisions that make them comfortable.

\section{REFERENCES}

Aday S. and Aday M.S. (2020). Impact of COVID-19 on the food supply chain. Food Qual. Safety, 4 (4), 167-180. DOI: $10.1093 /$ fqsafe/fyaa024

Adeniyi D.A., Dinbabo M.F. and Toerien D.F. (2020). Efficiency, food security and differentiation in smallscale irrigation agriculture: Evidence from Northwest Nigeria. Cogent Soc. Sci., 6 (1). DOI: 10.1080/23311886.2020.1749508

Ajadi D. (2010). Human Migration Guide, National Geography Expeditions (pp. 1-5)

Ajaero C.K. and Onokala P.C. (2013). The effects of rural-urban migration on rural communities of Southeastern Nigeria. Int. J. Population Res., pp. 1-10. https://doi.org/10.1155/2013/610193

Akanbi S. and Akinyoade A. (2014). Contributions of small and large-scale farms and foreign and local investments to agricultural growth: The Nigerian example. In: African Dynamics: Digging Deeper inside Africa's Agricultural, Food and Nutrition Dynamics. Brill: Leiden and Boston

Alarima C.I. (2018). Factors influencing rural-urban migration of youths in Osun State, Nigeria. AgroScience, 17 (3), 34-39. DOI: 10.4314/As.V17i3.6

Aliyu A. and Amadu L. (2017). Urbanization, cities, and health: The challenges to Nigeria - A review. Ann. Afr. Med., 16 (4), 149-158. DOI: 10.4103/aam.aam_1_17

Altieri M.A. and Nicholls C.I. (2020). Agroecology and the reconstruction of a post-COVID-19 agriculture. The J. Peasant Studies, 47 (5), 881-898. https://doi. org/10.1080/03066150.2020.1782891

Amare M., Abay K., Tiberti L. and Chamberlin J. (2020). Impact of COVID-19 on food security: Panel data evidence from Nigeria. Partnership for Economic Policy Working Paper 2020-2021. Retrieved 20 Aug. 2021 from: https://research4agrinnovation.org/wpcontent/uploads/2020/09/COVID-19_NigeriaWorking_Paper.pdf August, 2021 
Ameh J. (2020). Covid-19: Buhari names 12-member Presidential Task Force to control spread. Online: https://punchng.com/covid-19-buhari-names-12member-presidential-task-force-to-control-spread/

Anaglo J., Sakyi-Dawson O., Boateng S. and Mahama W. (2014). Perceived impacts of rural-urban migration on agricultural productivity in Nanumba South District of Northern Region of Ghana. Res. Human. Soc. Sci., 4 (4), 126-133

Andam K., Edeha H., Oboh V., Pauwc K. and Thurlowc J. (2020). Impacts of COVID-19 on food systems and poverty in Nigeria. In: Cohen M.J. (ed.), Advances in Food Security and Sustainability, Vol. 5. Chap. 4 (pp.145-173).https://doi.org/10.1016/bs.af2s.2020.09.002

Askew K. (2017). Food supplies and distribution are also strained as a result of population shifts. Retrieved from https://www.foodnavigator.com/article/2017/11 /10/population-growth-a-threat-to-food-quality

Aubry C. and Manouchehri N. (2019). Urban agriculture and health: Assessing risks and overseeing practices. In: Urban Agriculture: Another Way to Feed Cities, Field Actions Science Reports 20 (Special Issue), 108-111. journals.openedition.org/factsreports/5854

Ayanlade A. and Radeny M. (2020). COVID-19 and food security in sub-Saharan Africa: Implications of lockdown during agricultural planting seasons. Nature Partner J. Sci. Food, 4 (13). DOI: 10.1038/s41538020-00073-0

Ayieko M. and Njeru T. (2020). Why COVID-19 is another blow for Kenya's food security. Conversation. Online at: www.theconversation.com/why-covid-19is-another-blow-forkenyas-food-security-135567 Accessed 20/04/2021

Barrett C. (2020). Actions now can curb food systems fallout from COVID-19. Nature Food, 1, 319-320. https://doi.org/10.1038/s43016-020-0085-y

Carducci B., Keats E., Ruel M. et al. (2021). Food systems, diets and nutrition in the wake of COVID-19. Nat. Food, 2, 68-70. DOI: 10.1038/s43016-021-00233-9

Centres for Disease Control and Prevention (2021). COVID-19 Risks and Vaccine Information for Older Adults. Centres for Disease Control and Prevention (CDC). Available at https://www.cdc.gov/aging/ covid19/covid19-older-adults.html

Committee on World Food Security (2020). COVID-19 is threatening food security and workers' health. Discussion Paper for 21 Jul. 2020, Committee on World Food Security (CFS) Open Meeting

Dandekar H. (2015). Rural planning: General. IESBS, 801-806. DOI: 10.1016/B978-0-08-097086-8.74039-6

Erdal M. and Oeppen C. (2018). Forced to leave? The discursive and analytical significance of describing migration as forced and voluntary. J. Ethn. Migr. Stud., 44 (6), 981-998. DOI: 10.1080/1369183X.2017.1384149

Even M. and Nyathi P. (2020). Maintaining critical extension services for smallholders during COVID-19. https: //www.ifad.org/en/web/latest///blog/maintaining- critical -extension-services-for-smallholders-during-covid-1

Farrell K. (2018). An enquiry into the nature and causes of Nigeria's rapid urban transition. Urban Forum, 29, 277-298

FAO, IFAD, IOM and WTP (2018). The linkages between migration, agriculture, food security and rural development. Food and Agriculture Organization (FAO), International Fund for Agricultural Development (IFAD), International Organisation for Migration (IOM), and World Food Programme (WTP). Rome, 80 pp. http://www.fao.org/3/CA0922EN/CA0922EN.pdf
Federal Government of Nigeria, FGN (2020). Address by His Excellency Muhammadu Buhari, President of the Federal Republic of Nigeria on the COVID-19 Pandemic. 29th Mar. 2020, Abuja, Nigeria

Food and Agriculture Organization (2019). FAO migration framework - Migration as a choice and an opportunity for rural development. FAO, Rome. p. 128

Food and Agriculture Organization (2020). Impact of COVID-19 on agriculture, food systems and rural livelihoods in Eastern Africa: Policy and programmatic options. http://www.fao.org/3/cb0552en/CB0552EN.pdf

Frona D., Szenderak J. and Harangi-rakos M. (2019). The challenge of feeding the world. Sustainability, 11, 5816. DOI: $10.3390 /$ su11205816

Gebre T. and Gebremedhin B. (2019). The mutual benefits of promoting rural-urban interdependence through linked ecosystem services. Glob. Ecol. Conserv., 20. DOI: 10.1016/j.gecco.2019.e00707

Gengenbach H., Schurman R., Bassett T., Munro W. and Moseley W. (2018). Limits of the New Green Revolution for Africa: Reconceptualising gendered agricultural value chains. The Geogr. J., 184 (2), 208-214. https://doi.org/10.1111/geoj.12233

Ghebru H., Amare M., Mavrotas G. and Ogunniyi A. (2018). Role of land access in youth migration and youth employment decisions: Empirical evidence from rural Nigeria. NSSP Working Paper 58. International Food Policy Research Institute (IFPRI). http://ebrary. ifpri.org/cdm/ref/collection/p15738coll2/id/132895

Global Alliance for Improved Nutrition (2020). Impact of COVID-19 on Nigeria's food systems. Global Alliance for Improved Nutrition's (GAIN) Situation Report, Edition1,Nov.2020.Availableathttps://www.gainhealth. org/resources/reports-and-publications/impact-covid19-nigerias-food-systems-situation-report-edition-i

HLPE (2020). Impacts of COVID-19 on food security and nutrition: Developing effective policy responses to address the hunger and malnutrition pandemic. High Level Panel of Experts on Food Security and Nutrition (HLPE), Rome. DOI: 10.4060/cb1000en

Hoffmann E., Konerding V., Nautiyal S. and Buerkert A. (2019). Is the push-pull paradigm useful to explain rural-urban migration? A case study in Uttarakhand, India. PLoS ONE, 14 (4), e0214511. DOI: 10.1371/journal.pone.0214511

ILO (2020). The impact of the COVID-19 pandemic on jobs and incomes in G20 economies. International Labour Organisation (ILO). https://www.ilo.org/ wcmsp5/groups/public/---dgreports/---cabinet/docu ments/publication/wcms_756331.pdf

International Monetary Fund (2020). Regional Economic Outlook June 2020 Update: Sub-Saharan Africa. Washington, DC: IMF. https://www.imf.org/en/ Publications/REO/SSA/Issues/2020/06/29/sreo0629

Johnson K. and Ifeoma U. (2018). Rural development as a panacea for rural-urban migration in Nigeria. Art Human. Open Acc. J., 2 (5), 241-244. DOI: 10.15406/ahoaj.2018.02.00065

Kosec K., Ghebru H., Holtemeyer B., Mueller V. and Schmidt E. (2017). The effect of land access on youth employment and migration decisions: Evidence from rural Ethiopia. Amer. J. Agric. Econ., 100 (3), 931-954. https://doi.org/10.1093/ajae/aax087

Kuddus M., Tynan E. and McBryde E. (2020). Urbanization: A problem for the rich and the poor? Public Health Rev., 41, 1. DOI: 10.1186/s40985-019-0116-0 
Mbah E., Ezeano C. and Agada M. (2016). Effects of rural-urban youth migration on farm families in Benue State, Nigeria. Int. J. Agric. Res. Innov. Technol., 6 (1), 14-20. Available online at http://www.ijarit.webs.com

Mellor J.W. (2017) Poverty, food security, and nutrition. In: Agricultural Development and Economic Transformation. Palgrave Studies in Agricultural Economics and Food Policy. DOI: 10.1007/978-3-319-65259-7_4

Moseley W.G. (2017). A risky solution for the wrong problem: Why GMOs won't feed the hungry of the world. Geogr. Rev., 107 (4), 578-583. https://doi. org/10.1111/gere. 12259

Moseley W.G. (2020). The geography of COVID-19 and a vulnerable global food system. World Politics Review, May 12. Available at https://www.world politicsreview.com/articles/28754/the-geography-ofcovid-19-and-avulnerable-global-food-system

Newborne P. (2016). Water for cities and rural areas in contexts of climate variability: Assessing paths to shared prosperity - the example of Burkina Faso. Retrieved online at https://journals.openedition.org/ factsreports/4042

Nicholls E., Ely A., Birkin L., Basu P. and Goulson D. (2020). The contribution of small-scale food production in urban areas to the sustainable development goals: A review and case study. Sustain. Sci., 15, 15851599. DOI: $10.1007 / \mathrm{s} 11625-020-00792-\mathrm{z}$

NCDC (2020). First case of corona virus disease confirmed in Nigeria. Nigeria Centre for Disease Control (NCDC). https://ncdc.gov.ng/news/227/firstcase-of-corona-virus-disease-confirmed-in-nigeria

NCDC (2021). COVID-19 Nigeria. Nigeria Centre for Disease Control (NCDC). https://covid19.ncdc.gov.ng

Obayelu A., Obayelu O., Bolarinwa K. and Oyeyinka R.A. (2021). Assessment of the immediate and potential long-term effects of COVID-19 Outbreak on socioeconomics, agriculture, security of food and dietary intake in Nigeria. Food Ethics, 6, 5. DOI: 10.1007/s41055-021-00085-w

OECD (2020). Food supply chains and COVID-19: Impacts and policy lessons. OECD Policy Response to Coronavirus. https://www.oecd.org/coronavirus/ policy-responses/food-supply-chains-and-covid-19impacts-and-policy-lessons-71b57aea/

Ofuoku A., Opia B. and Ikpoza E. (2021). Impact of COVID-19 induced rural-rural migration on agricultural productivity in Delta State, Nigeria. Sci. Agro., 12 (1). DOI: 10.17268/sci.agropecu.2021.006

Oginni O. and Tahirou A. (2019). Impacts of rural-urban migration of youths on household's welfare in Nigeria. Invited Paper Presented at the $6^{\text {th }} A f r$. Confer. Agric. Econ., 23-26 Sep., Abuja

Oguche C., Diyoke M., Ogar P. and Nasir Y. (2020). Paradox of migration in Nigeria (rural- urban): Issues and challenges. J. Soc. Sci. Edu. Human., 2, 36-42

Oni-Jimoh T., Linayage C., Oyebanji A. and Gerges M. (2018). Urbanization and meeting the need for affordable housing in Nigeria. In: Almusaed A. and Almssad A. (eds.), Housing. DOI: 10.5772/intechopen. 78576

Omonijo D.O., Toluwase S.O.W., Oludayo O.A. and Onyekwere O.O.C. (2014). Impacts of Agricultural Development Programme (ADP) on rural dwellers in Nigeria: A study of Isan-Ekiti. Int. Res. J. Fin. Econ., 128, 41-55

Organisation for Economic Co-operation and Development (2020). Coronavirus (COVID-19): SME policy responses. https://www.oecd.org/coronavirus/policyresponses/coronavirus-covid-19-sme-policyresponses-04440101/
Pan D., Yang J., Zhou G. and Kong F. (2020). The influence of COVID-19 on agricultural economy and emergency mitigation measures in China: A text mining analysis. PLOS ONE, 15 (10), e 0241167. DOI: 10.1371/journal.pone.0241167

Parrish R., Colbourn T., Lauriola P. et al. (2020). A critical analysis of the drivers of human migration patterns in the presence of climate change: A new conceptual model. Int. J. Environ. Res. Public Health, 17, 6036

Presidential Task Force (2020). Implementation Guidance for Lockdown Policy. Abuja, Nigeria. https://state house.gov.ng/wp-content/uploads/2020/04/PTFCOVID-19-Guidance-on-implementation-oflockdown-policy-FINAL.docx-2.pdf

Resnick D. (2020). Covid-19 lockdowns threaten Africa's vital informal urban food trade. https://www.ifpri.org/ blog/covid-19-lockdowns-threaten-africas-vitalinformal-urban-food-trade

Rosenberg M. (2021). Push-Pull Factors in Immigration. https://www.thoughtco.com/push-pull-factors-1434837

Singirankabo U.A. and Ertsen M.W. (2020). Relations between land tenure security and agricultural productivity: Exploring the effect of land registration. Land, 9, 138. DOI: 10.3390/land9050138

Stephens E., Martin G., Wijk M., Timsina J. and Snow V. (2020). Editorial: Impacts of COVID-19 on agricultural and food systems worldwide and on progress to the sustainable development goals. Agric. Sys., 183, 102873. DOI: 10.1016/j.agsy.2020.102873

Stewart A., Kottasová I. and Khaliq A. (2020). Why meat processing plants have become COVID-19 hotbeds. CNN, Jun. 27. https://www.cnn.com/ 2020/06/27/ health/meatprocessing-plants-coronavirus-intl/index.html

Udemezue J.C. (2019). Challenges and opportunities of agricultural sector among youths in the twenty first century: The case of Nigeria. Adv. Biotechnol. Microbiol., 14 (5), 555896

Wang S. and Yu B. (2019). Labor mobility barriers and rural-urban migration in transitional China. China Econ. Rev., 53, 211-224

World Bank (2019). Rural population (\% of total population) - Nigeria. Retrieved from: https://data.worldbank. org/indicator/SP.RUR.TOTL.ZS?locations $=\mathrm{NG}$

World Bank (2020a). World bank predicts sharpest decline of remittances in recent history. Online at https://www.worldbank.org/en/news/press-release/ 2020/04/22/world-bank-predicts-sharpest-decline-ofremittances-in-recent-history

World Bank (2020b). Agriculture and food. Online at https: //www.worldbank.org/en/topic/agriculture/overview

World Economic Forum. (2017). Migration and its impact on cities. Online at http://www3.weforum.org/ docs/Migration_Impact_Cities_report_2017_low.pdf

Yaffe-Bellany D. and Corkery M. (2020). Dumped milk, smashed eggs, plowed vegetables: The food waste of the pandemic. New York Times, Apr. 11. Available at https://www.nytimes.com/2020/04/11/business/coron avirus-destroying-food.html? searchResultPosition=1

Yeboah F., Jayne T., Muyanga M. and Chamberlin J. (2019). Youth access to land, migration and employment opportunities: Evidence from sub-Saharan Africa. IFAD Res. Series. Online at https://www.ifad. org/documents/38714170/41187395/13_Yeboah+et+ al. $2019+$ RDR+BACKGROUND+PAPER.pdf/49d1 61 d8-bc5a-e154-fdb4-0d2d032a2f29

Zhang S., Deng W., Peng L., Zhou P. and Liu Y. (2020). Has rural migration weakened agricultural cultivation? Evidence from the mountains of Southwest China. Agric., 10 (3), 63. DOI: 10.3390/agriculture10030063 